\title{
The Water Environment Carrying Capacity of the Aiyi River Based on Artificial Neural Networks
}

\author{
Xiaoli Kai, ${ }^{1,4}$ Xiaocong Qiu'*, Yan Wang², Weijiang Zhang1,3, Juan Yin ${ }^{1,3}$ \\ ${ }^{1}$ School of Civil Engineering and Hydraulic Engineering, Ningxia University, Yinchuan, China \\ ${ }^{2}$ School of Life Science, Ningxia University, Yinchuan, China \\ ${ }^{3}$ Key Laboratory of Restoration and Rehabilitation of Degraded Ecosystems in Northwestern China, \\ Ministry of Education, Yinchuan, China \\ ${ }^{4}$ Earth and Environmental College, Anhui University of Science and Technology, Huainan, China
}

Received: 9 September 2018

Accepted: 11 December 2018

\begin{abstract}
To understand the characteristics of the water's environmental carrying capacity in the Aiyi River in Yinchuan, Ninxia, China, a BP artificial neural network analysis based on water environmental factors and aquatic biodiversity metrics were conducted. Twelve indicators were used to construct an evaluation index system to examine the water environment carrying capacity of the river, namely ratio of water supply and water requirements; ratios of water environmental capacity to pollutant emissions of $\mathrm{COD}_{\mathrm{Mn}}$, $\mathrm{BOD}_{5}, \mathrm{TN}, \mathrm{NH}_{3}-\mathrm{N}$, and TP; self-purification rate; biodiversity indices of phytoplankton, zooplankton zoobenthos, and aquatic macrophytes; and a comprehensive nutrition state index. A model of water environmental carrying capacity was constructed according to the BP artificial neural network. The model, which quantitatively analyzed the water environmental carrying capacity of the Aiyi River, found it to be in the basic carrying state.
\end{abstract}

Keywords: Aiyi River, water environmental carrying capacity, indicator system, model of BP artificial neural network

\section{Introduction}

Water shortages and degradation of the water environment have become major constraints on the sustainability of economic and social development in China. Water environment is crucial to the existence and development of social and economic systems,

*e-mail: qxc7175@126.com and its carrying capacity status plays an important role in regional development [1-3]. Therefore, studies on water environment capacity, optimization of water resources, and water environment protection are necessary [4-7]. Furthermore, it is important to coordinate production, living water resources and water environments to achieve sustainable development in the region.

Water resources are scarce in the Ningxia Hui Autonomous Region of China, where the dry and windy conditions and sparse vegetation limit the environment's 
capacity; the ecosystem stability is poor; and the water environment is vulnerable to pollution and destruction. Severe regional water pollution has become a serious environmental issue. Aiyi River, located in Ningxia, is planned for flood control, drainage, and landscape development to create a key water conservation region as part of the Connect Rivers and Lakes Project in Yinchuan. The river is a national scenic area, with planned developments aiming to improve flood control and drainage conditions in Yinchuan, regulate the water table, beautify the living environment, improve urban quality, and achieve harmony between people and water. The river has important social significance and far-reaching historical significance. The total length of the Aiyi is $158.5 \mathrm{~km}$, and the water area is more than $3.33 \mathrm{~km}^{2}$ and covers a drainage area of about $11,667 \mathrm{~km}^{2}$. Up to 51 million $\mathrm{m}^{3}$ of water in the river's upper section can be reused each year. The water is mainly comprised of floodwater, ditch water and drained channel water, with $68.9 \%$ of this water coming from farmland drainage. The water is rich in nitrogen and phosphorus. Pollution from agriculture and rural nonpoint sources are also becoming a basic constraint on the river's water quality. Withdrawn water pollution of irrigated areas, with farmland as the core, is becoming a major contaminative source influencing Aiyi water quality. Because of the massive import of exogenous nutrients and the weak river water exchange, the river's water body has gradually become eutrophic.

The structure and function of aquatic ecosystems is the primary element of the water environment carrying capacity (WECC). Although ecological limits of the WECC define why a water environment exists with the carrying capacity limit, previous research has shown that economics and populations were focused on the carrying index. There is a lack of research on aquatic ecosystems and water self-purification capacity, including the determination of ecological water, not deep into the WECC. In this study, we developed a mechanistic system, including ecological environmental water demand, water purification capacity, and an aquatic biological diversity index factor of the Aiyi River environment in order to determine water environment quality. Through the establishment of a BP artificial neural network model, we conducted quantitative research to provide a theoretical basis for protecting and managing the river.

\section{Materials and Methods}

\section{Aiyi River WECC Index}

The WECC is the ability of a water environment system to accommodate pollutants while continuing to function normally and maintaining good ecosystem functioning. It defines the index value or the ideal value under the constraints of certain conditions. To correctly understand the meaning of the WECC and conduct

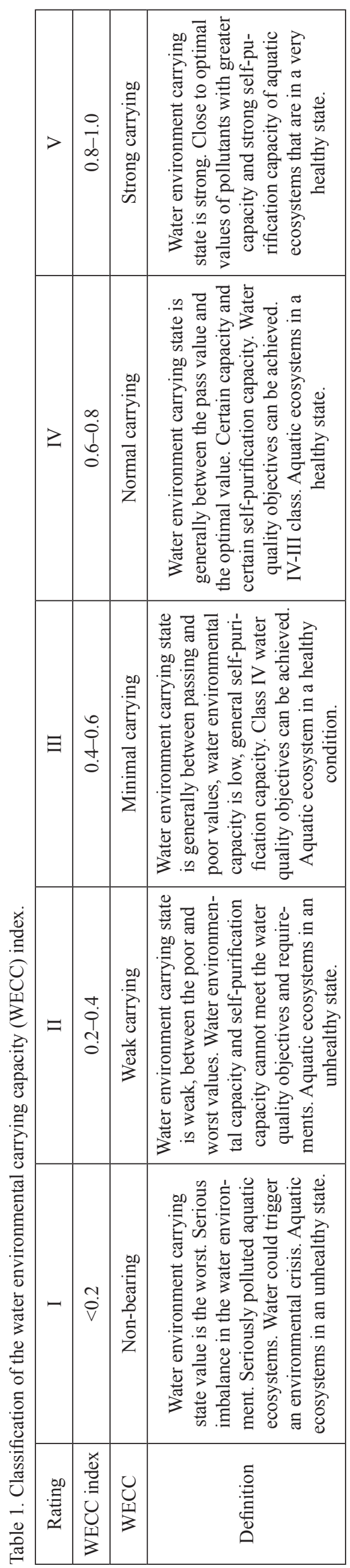




\begin{tabular}{|c|c|c|}
\hline \multicolumn{3}{|c|}{ Aiyi River WECC Evaluation System } \\
\hline$\sqrt{ }$ & & 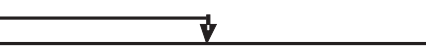 \\
\hline Water quality subsystem & Water quantity subsystem & Water ecology subsystem \\
\hline $\begin{array}{l}\text { 1. COD capacity, emissions ; } \\
\text { 2. } \mathrm{BOD}_{5} \text { capacity, emissions ; } \\
\text { 3. } \mathrm{TN} \text { capacity, emissions ; } \\
\text { 4. TP capacity, emissions; } \\
\text { 5. } \mathrm{NH}_{3}-\mathrm{N} \text { capacity, emissions; } \\
\text { 6. Self-purification rate; } \\
\text { 7. Trophic state index. }\end{array}$ & $\begin{array}{l}\text { 1.Water su pply, } \\
\text { water demand. }\end{array}$ & $\begin{array}{l}\text { 1. Phytoplankton diversity } \\
\text { index; } \\
\text { 2. Zooplankton diversity } \\
\text { index; } \\
\text { 3. Zoobenthos diversity } \\
\text { index; } \\
\text { 4. Aquatic plants diversity } \\
\text { index. }\end{array}$ \\
\hline
\end{tabular}

Fig. 1. Aiyi River WECC evaluation system.

a quantitative study, we examined various studies that applied the WECC [8].

To evaluate the WECC, $n$ indicators of a river were selected, with the corresponding index value represented by a vector $\mathrm{C}=\left(\mathrm{C}_{1}, \mathrm{C}_{2} \ldots \mathrm{C}_{\mathrm{n}}\right)$. Indices were set for the corresponding threshold vector $\mathrm{C}_{0}=\left(\mathrm{C}_{01}, \mathrm{C}_{02} \ldots . . \mathrm{C}_{0 \mathrm{n}}\right)$. The WECC index for the river was thus: $D=C / C_{0}$.

Quantifying the Aiyi River WECC, according to international, national, industry and local regulations, standards and literature [8-10] resulted in a classification of "non-bearing", " weak carrying", "minimal carrying", "normal carrying" or "strong carrying" (Table 1). Using this classification, the water environment carrying status of the Aiyi can be determined intuitively.

\section{Aiyi River WECC Evaluation System}

The indicator system was determined on the basis of the WECC's characteristics, referencing and drawing from existing research results, following the principles, regionality, motility and quantifiables. Besides, according to the actual situation of the river, including environmental factors of water, aquatic organisms and their diversity, water environmental capacity, selfpurification capacity, and ecology environmental water demand. From three categories of water quantity, water quality, and water ecosystems, 12 indicators were selected for setting up the Aiyi River WECC evaluation system (Fig. 1).

Taking Chinese Standard of Class IV (GB38382002) water and the water eutrophication indicators as a baseline, we determined the standard indicators for WECC as three arrangements of ideas for each indicator; the worst, qualified and optimal values. According to the requirements of the water environment, the optimal value is defined as when one index achieves the optimal value, and the qualified value is when one index achieves the lowest value and the worst value is when one index is lower than the lowest value, respectively.

\section{Water Quantity Subsystem}

The water quality evaluation index was determined by dividing the water supply by water demand. When the water quality of the Aiyi meets the requirements of national surface water quality standard Class IV, the ecological and environmental water demand reached $98,781,800 \mathrm{~m}^{3}$. When the annual water supply was $\geq 110,566,900 \mathrm{~m}^{3}$, the water quality reached Class III or above. When the annual water supply was $\leq 92,892,500 \mathrm{~m}^{3}$, the water quality reached Class V or lower. When the water supply/water demand $=1$, the Aiyi River water quality reached Class IV. When the water supply/water demand $=1.12$, water quality reached Class III or above. When the water supply/ water demand was $\leq 0.94$, water quality was Class V or lower. Thus, the qualified value was defined as when water supply/water demand $=1$, optimal as when water supply/water demand $=1.2$, and the worst when water supply/water demand $=0.8$.

\section{Water Quality Subsystem}

We calculated the water environmental capacity/ emission values when the water quality was Class III, $\mathrm{IV}$, and $\mathrm{V}$ by taking the water environmental capacity of the Aiyi when the quality was Class IV as the cardinal number. When the environmental capacity/ pollutant emissions $=1$, Aiyi water quality met the national surface water quality standard Class IV, and was used as the qualified value. Water environmental capacity/pollutant emissions value were defined as at an optimum value when water quality was the national surface water quality standard Class III or above. Water environmental capacity/pollutant emissions values were defined as the worst value, when water quality was the national surface water quality standard Class $\mathrm{V}$ or lower. We then calculated the optimum and worst values of $\mathrm{COD}_{\mathrm{Mn}}, \mathrm{BOD}_{5}, \mathrm{TN}, \mathrm{NH}_{3}-\mathrm{N}$, and TP capacity/emissions.

Taking the national surface water quality standards as the basis, $\mathrm{N}$ was the main pollutant for the Aiyi 
and thus TN self-purification rate was used as the grading standard. The TN concentration was used as the cardinal number, and the rate of self-purification of water bodies, when purifying the water for classes III, IV and V, was calculated. When the self-purification rate was $=0.57$, water could be purified for Class IV and used as the qualified value. When the self-purification rate was $\geq 0.71$, water could be purified for class III and above and used as the optimal value. Finally, when the self-purification rate $\leq 0.43$, water could be purified for class $\mathrm{V}$ or below and used as the worst value.

According to the relevant regulations of "lakes (reservoirs) eutrophication assessment methods and classification technology requirements," we took a comprehensive trophic state index of 50 to represent the medium nutrition, which was used as the qualified value, $\leq 30$ was poor nutrition and thus the optimal value, and $\geq 70$ was severe eutrophication and used as the worst value. A reciprocal value of the trophic state index was used here to easily compare the numerous indicators in this study.

\section{Water Ecological Subsystem}

The water ecological subsystem includes four indices: the Shannon-Wiener diversity index of phytoplankton, zooplankton, benthic fauna, and aquatic plants. The Shannon-Wiener diversity index reflects the diversity of a community of species; an H' value of 0-1 indicates eutrophication, 1-3 was medium nutrition, and $>3$ was poor nutrition [11]. Accordingly, $\mathrm{H}^{\prime}=2$ was taken as the qualified value, $H^{\prime} \geq 4$ as the optimal value, and $H^{\prime} \leq 1$ as the worst value. The Aiyi water environmental carrying capacity (WECC) evaluation grading criteria are shown in Table 2.

\section{BP Artificial Neural Network Model of the Aiyi River's WECC}

The calculation of the WECC index involves multiple evaluations and weight determinations. Thus, this paper used a powerful nonlinear processing system using the sample data weight artificial neural network technology in order to establish the following WECC quantitative model based on the BP artificial neural network:

$$
\left\{\begin{array}{c}
\text { Input layer: } \sum_{i=1}^{m} \operatorname{input}\left(C_{i}\right) \\
\text { Hidden layer: } n_{1}=\sqrt{m+n}+a \\
\text { Output layer: } \sum_{j=1}^{n} \operatorname{output}\left(D_{j}\right)
\end{array}\right.
$$

In the mode $C_{i} \in C, C=\left\{C_{1}, C_{2}, \ldots, C_{m}\right\} ; \mathrm{n} 1 n_{1}$ is the number of neurons in the hidden layer, $m$ is the number of neurons in the input layer, $n$ is the number of neurons in the output layer, and $a$ is a constant of 1 to 10 ; $D_{i} \in D, D=\{D\}$.

The model input layer corresponds to the evaluation value of WECC, and the output layer corresponds to the WECC index, with the number of neurons in the hidden layer generally obtained by trial and error. When using this model for calculation, the output value is the regional water environment carrying capacity index.

We established a BP artificial neural network model of the Aiyi's WECC, in which $\mathrm{C}_{1}, \mathrm{C}_{2}$, ..., $\mathrm{C}_{11}$ were the inputs, and the WECC index was the output, as shown in Fig. 2. Sample data were selected in this way, surpassing the selecting optimal value vector $\mathrm{C}_{\text {Optimal }}=\left(\mathrm{C}_{\text {1Optimal }}, \mathrm{C}_{\text {2Optimal }}, \mathrm{C}_{3 \text { Optimal }}, \mathrm{C}_{4 \text { Optimal }}, \mathrm{C}_{5 \text { optimal }}\right)$;

Table 2. Assessment indicator values from the standard system of WECC in the Aiyi.

\begin{tabular}{|c|c|c|c|c|c|c|}
\hline Index & Code & Worst value & Worse value & Qualified value & Better value & Optimal value \\
\hline Water supply, water demand & $\mathrm{C}_{1}$ & 0.80 & 0.90 & 1.00 & 1.10 & 1.20 \\
\hline $\mathrm{COD}_{\mathrm{Mn}}$ capacity, emissions & $\mathrm{C}_{2}$ & 0.60 & 0.80 & 1.00 & 1.59 & 2.17 \\
\hline $\mathrm{BOD}_{5}$ capacity, emissions & $\mathrm{C}_{3}$ & 0.54 & 0.77 & 1.00 & 1.36 & 1.72 \\
\hline TN capacity, emissions & $\mathrm{C}_{4}$ & 0.47 & 0.74 & 1.00 & 2.00 & 3.00 \\
\hline $\mathrm{NH}_{3}-\mathrm{N}$ capacity, emissions & $\mathrm{C}_{5}$ & 0.70 & 0.85 & 1.00 & 1.36 & 1.72 \\
\hline TP capacity, emissions & $\mathrm{C}_{6}$ & 0.73 & 0.87 & 1.00 & 1.30 & 1.59 \\
\hline Self-purification rate & $\mathrm{C}_{7}$ & 0.43 & 0.5 & 0.57 & 0.64 & 0.71 \\
\hline Phytoplankton diversity index $\mathrm{H}^{\prime}$ & $\mathrm{C}_{8}$ & 1 & 1.5 & 2 & 3 & 4 \\
\hline Zooplankton diversity index $\mathrm{H}^{\prime}$ & $\mathrm{C}_{9}$ & 1 & 1.5 & 2 & 3 & 4 \\
\hline Zoobenthos diversity Index $\mathrm{H}^{\prime}$ & $\mathrm{C}_{10}$ & 1 & 1.5 & 2 & 3 & 4 \\
\hline Aquatic plant diversity index $\mathrm{H}^{\prime}$ & $\mathrm{C}_{11}$ & 1 & 1.5 & 2 & 3 & 4 \\
\hline Trophic state index & & 70 & 60 & 50 & 40 & 30 \\
\hline 1/Trophic state index & $\mathrm{C}_{12}$ & 0.014 & 0.017 & 0.020 & 0.025 & 0.033 \\
\hline WECC Index & & 0.2 & 0.4 & 0.6 & 0.8 & 1.0 \\
\hline
\end{tabular}




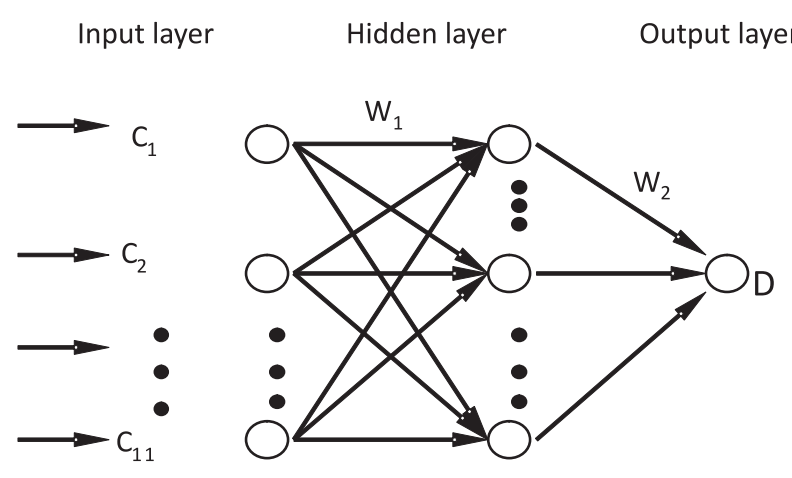

Fig. 2. Structure of artificial neural network model for water environment carrying capacity.

the qualified value vector $\mathrm{C}_{\text {Qualified }}=\left(\mathrm{C}_{1 \text { Qualified }}, \mathrm{C}_{2 \text { Qualified, }}\right.$, $\mathrm{C}_{3 \text { Qualified }}, \mathrm{C}_{4 \text { Qualified }}, \mathrm{C}_{5 \text { Qualified }}$ ); and the worst value vector $\mathrm{C}_{\text {Worst }}=\left(\mathrm{C}_{1 \text { Worst }}, \mathrm{C}_{2 \text { Worst }}, \mathrm{C}_{3 \text { Worst }}, \mathrm{C}_{4 \text { Worst }}, \mathrm{C}_{5 \text { Worst }}\right) ; \mathrm{C}_{\text {Better }}=$ $\left(\mathrm{C}_{\text {Optimal }}+\mathrm{C}_{\text {Qualified }}\right) / 2 ; \mathrm{C}_{\text {Worse }}=\left(\mathrm{C}_{\text {Qualified }}+\mathrm{C}_{\text {Worst }}\right) / 2$.

Based on the above assumptions, $\mathrm{C}_{\text {Optimal }}, \mathrm{C}_{\text {Better' }}$, $\mathrm{C}_{\text {Qualified }}, \mathrm{C}_{\text {Worse, }}$ and $\mathrm{C}_{\text {Worst }}$ were defined as the inputs, with the corresponding outputs of $1.0,0.8,0.6$, $0.4,0.2$, respectively. After the model learning 2000 times, with an error of 0.00038 , evaluation of the environmental carrying capacity was used to establish the river artificial neural network model in the Aiyi, and the input sample data used to fit the computergenerated model. Adopted Aiyi River actual data 2010 as input, calculating Aiyi River WECC index, and evaluating Aiyi River's WECC (Fig. 2).

\section{Results}

The connection weights and thresholds of the input layer and hidden layer as shown in the matrix $\mathrm{W}_{1}$.

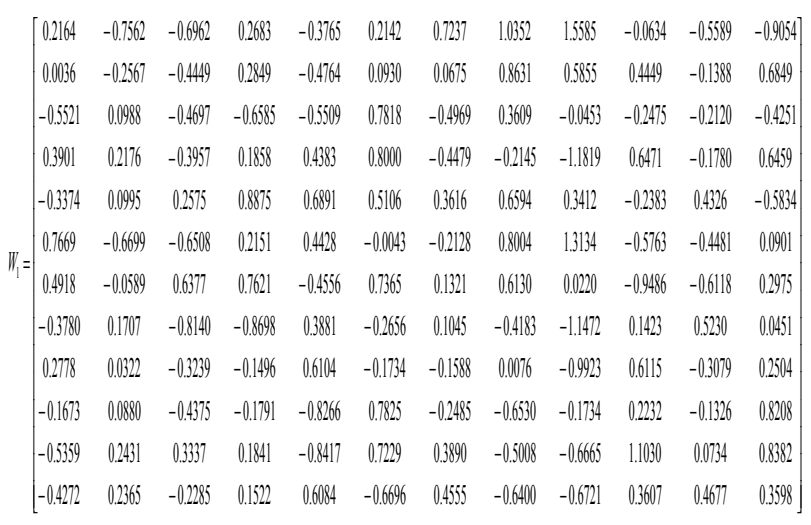

The connection weights and threshold of the hidden layer and output layer as shown in the matrix $\mathrm{W}_{2}$.

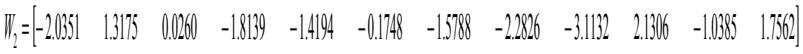

The sample data was input to perform the fitting calculation of the established model, and the fitted value
Table 3. Sample data.

\begin{tabular}{|c|c|c|c|}
\hline Sample & $\begin{array}{c}\text { Expected } \\
\text { value }\end{array}$ & $\begin{array}{c}\text { Fitted } \\
\text { value }\end{array}$ & $\begin{array}{c}\text { Relative error } \\
(\%)\end{array}$ \\
\hline Sample 1 & 0.2 & 0.208 & 4.00 \\
\hline Sample 2 & 0.4 & 0.390 & 2.50 \\
\hline Sample 3 & 0.6 & 0.585 & 2.50 \\
\hline Sample 4 & 0.8 & 0.835 & 4.38 \\
\hline Sample 5 & 1.0 & 0.954 & 4.60 \\
\hline
\end{tabular}

and relative error were shown in Table 3 . When the relative errors between the fitted value and the expected output value was less than $5.00 \%$, and the model could be used to calculate the WECC.

The Aiyi River's WECC index is shown in Table 4. The Aiyi River's WECC was in good condition in March, was normal in July and September, and was weak in May and November. The annual average was in the basic bearer status.

\section{Discussion}

\section{Definition of WECC}

The WECC is a combination of the concept of carrying capacity and water environmental fields. Systematic results have not yet been obtained from combinations of the content, features, changes and quantitative characterization of the elements of the water environment carrying system. Thus, academia has not yet reached a general consensus on the WECC definition. It can be summarized into the following three categories: 1) according to "pollution receiving capacity", such as "in a certain waters, its water can continue to be used and still maintain a good ecological system, which can accommodate a maximum capacity of sewage and pollutants"[12-15] and "Under the premise of sustainable water environment system functions, the ability to accept pollutants and the ability to bear the change of the basic elements" [1617]; 2) according to "supporting ability", such as "in a certain region, at a time, under some state, the threshold of the needs of economic development and the ability to support life for water environment" [18-19]; 3) according to "external action", such as "under the premise of basin water environment system structural features and functions are not a qualitative change, basin water environment system can withstand the maximum external action" [20-21]. By examining research in recent years on the various different definitions of water environmental carrying capacity, this paper can argue that the WECC can be defined as the ability of water environment systems to accept pollutants and its capacity to sustain normal ecosystem function. 
Table 4. Data and indices for water environmental carrying capacity in the Aiyi.

\begin{tabular}{|c|c|c|c|c|c|c|c|}
\hline Index & Code & March & May & July & September & November & Average \\
\hline Water supply, water demand & $\mathrm{C} 1$ & 0.403 & 0.447 & 0.461 & 0.564 & 0.55 & 0.49 \\
\hline $\mathrm{COD}_{\mathrm{Mn}}$ capacity, emissions & $\mathrm{C} 2$ & 22.46 & 2.80 & 1.20 & 2.15 & 2.91 & 4.07 \\
\hline $\mathrm{BOD}_{5}$ capacity, emissions & $\mathrm{C} 3$ & 26.51 & 3.32 & 1.58 & 3.17 & 4.37 & 5.38 \\
\hline TN capacity, emissions & $\mathrm{C} 4$ & 2.77 & 0.01 & 0 & 0.52 & 0.40 & 0.50 \\
\hline $\mathrm{NH}_{3}-\mathrm{N}$ capacity, emissions & $\mathrm{C} 5$ & 15.00 & 3.23 & 2.48 & 4.36 & 2.74 & 5.09 \\
\hline TP capacity, emissions & C6 & 27.78 & 11.67 & 6.18 & 11.89 & 9.68 & 12.69 \\
\hline Self-purification rate & $\mathrm{C} 7$ & 0.226 & 0.309 & 0.383 & 0.345 & 0.169 & 0.26 \\
\hline Phytoplankton diversity index $\mathrm{H}^{\prime}$ & $\mathrm{C} 8$ & 3.424 & 3.443 & 3.178 & 2.974 & 3.485 & 3.334 \\
\hline Zooplankton diversity index $\mathrm{H}^{\prime}$ & C9 & 2.522 & 2.721 & 3.033 & 2.861 & 3.231 & 2.958 \\
\hline Zoobenthos diversity Index $\mathrm{H}^{\prime}$ & $\mathrm{C} 10$ & 2.043 & 2.004 & 2.284 & 2.175 & 1.575 & 2.016 \\
\hline Aquatic plant diversity index $\mathrm{H}^{\prime}$ & $\mathrm{C} 11$ & 2.441 & 2.002 & 2.118 & 2.294 & 2.410 & 2.424 \\
\hline $1 /$ Trophic state index & $\mathrm{C} 12$ & 0.019 & 0.018 & 0.016 & 0.018 & 0.018 & 0.018 \\
\hline Trophic state index & & 0.6285 & 0.5444 & 0.6209 & 0.5680 & 0.5155 & 0.5800 \\
\hline WECC Index & & Can carry & $\begin{array}{c}\text { Basic can } \\
\text { carry }\end{array}$ & Can carry & $\begin{array}{c}\text { Basic can } \\
\text { carry }\end{array}$ & $\begin{array}{c}\text { Basic can } \\
\text { carry }\end{array}$ & $\begin{array}{c}\text { Basic can } \\
\text { carry }\end{array}$ \\
\hline
\end{tabular}

\section{Aiyi WECC Index}

According to the definition of the concept of WECC, users choose different indicator systems and use different methods to study water environmental carrying capacity. However, current research on the WECC mainly focuses on socio-economic systems, with a lack of integration of aquatic ecosystems, water purification capacity, and eco-environmental water variables. The pressure of the socio-economic system on the water environment is an external force. This is in contrast to the water environment carrying capacity, which takes their resultant force to represent the WECC. It will confuse the internal forces and external forces of carrier and being carrier. Therefore, accurately measuring the WECC in relation to socio-economic system carrying capacity is difficult. Thus, the effect of WECC on social, economic and demographic goals can be summarized as the carrying capacity of water quantity and water quality. Quantitative research on water environmental carrying capacity considerations should focus on the relationship between water supply and water demand, water quality and aquatic ecosystems; this paper will thus use these as the basis for analysis and research.

Aquatic ecosystems include producers (phytoplankton, aquatic plants), consumers (zooplankton, fish, benthic animals), and decomposers (bacteria). Phytoplankton, aquatic plants and bacteria are the main contributors to biological self-purification of water bodies, and their composition and biomass directly determine the biological self-purification capacity of water bodies. The composition and biomass of zooplankton, fish, and benthic animals affect the composition and biomass of phytoplankton, aquatic plants and bacteria, and thus indirectly affect the biological self-purification capacity of water bodies. According to the definition of water environmental carrying capacity in this paper, a diversity index characterizing the structure and biomass of aquatic ecosystems was introduced into the evaluation system of the WECC. Due to the complex structure of aquatic ecosystems, there is a lack of current research on aquatic plants, bacteria, aquatic ecosystems and water environmental carrying capacity evaluation. Thus, this paper chose the phytoplankton diversity index, zooplankton diversity index, and benthic fauna diversity index as evaluation indices. In the future, we need to introduce water plants, bacteria and other aquatic organisms into the analysis in order to improve studies of water environmental carrying capacity study.

Eco-environmental water demand refers to the minimum amount of water needed for the maintenance of ecosystem stability without ecological degradation [22-23]. Ecological water demand refers to the water required for maintaining water biome habitat dynamic stability [24-25]. Furthermore, environmental water demand refers to the water needed to meet the basic functions of a healthy ecosystem in order to protect and improve the water environment [26]. Water is the media and power maintaining normal system structure and function [27]. Ensuring that there is enough water in the river to meet the needs of river ecosystems and the environment is of important significance to water safety and aquatic ecosystem health. In this paper, water supply and ecological water requirements were introduced as an evaluation index system of the water environment bearing mechanism in order to analyze the WECC. 
Water environmental capacity and water purification capacity are important parts of the environmentbearing mechanism system, and the size of the water environment carrying capacity is closely related. Water environmental capacity refers to the maximum allowable capacity of water pollutants per unit of time for a certain water body, under the premise that its function is not damaged. The limit of water environmental capacity is an important reason for water environmental carrying the existence of limit. Following contamination, water ecosystems, through the process of natural ecological processes and material circulation, absorb, transform and redistribute the water pollutants so that the water will be purified, and restored to its natural state [2831]. This process is called self-purification, and selfpurification capacity is an important indicator of the health of aquatic ecosystems [32-34]. Further, selfpurification has an important influence on water environmental carrying capacity. This paper chose water environmental capacity, pollutant emissions and water self-purification rate as the evaluation indices to analyze the WECC in water quality.

It should be pointed out that the selected indicators are dimensionless, and thus we do not have to consider dimensional inconsistencies when the indicators are applied in modeling.

\section{Aiyi River WECC}

The Aiyi River WECC showed significant seasonal trends. In March, the WECC was in a "normal carrying" state; fewer pollutants flowed into the river, and the remaining water environmental capacity was higher than in other months. The assimilative capacity was also strong in March, and the water was mildly eutrophic, so the WECC was in a "normal carrying" state. In May, the volume of channel water increased, as did the level of pollutants. Therefore, the remaining water environmental capacity decreased, and river water demand for self-purification increased. During this period, nursery fish and other aquatic animals were spawning, and the basic ecological water demand increased, so the WECC was in a basic "normal carrying" state. In July, aquatic organisms grew rapidly, and the biodiversity indices rose. Furthermore, the self-purification capacity of the water bodies significantly improved, and thus the carrying capacity had increased compared with that of May, and the WECC was in a "normal carrying" state. In September and November, the amount of river water had increased significantly, the levels of pollutants in the water had increased, the remaining water environmental capacity was reduced, and the water demand of selfpurification increased. At the same time, aquatic plants gradually disappeared and water purification capacity was dramatically reduced, and therefore the carrying capacity was weak.
In this comprehensive analysis, the Aiyi River's WECC was weak. The annual average was a basic "can carry" state. The main reason for this level was that the Aiyi River water was primarily from agricultural water withdrawal, in which TN is high. Therefore, the demand for purified river water exceeded the supply quantity, and the WECC was weak. In the future, the Aiyi River water environment governance should increase ecological filling water and reduce the emissions of pollutants.

\section{Conclusions}

By using measurements of the environmental variables of Aiyi River water, along with the diversity of aquatic organisms, we determined the water environmental capacity, self-purification capacity, and ecological and environmental water demand. From the variables of water quantity, water quality, and aquatic ecosystems, we selected 12 indicators (Water supply/ water demand, $\mathrm{COD}_{\mathrm{Mn}}$ Capacity/emissions, $\mathrm{BOD}_{5}$ capacity/emissions, TN capacity/emissions, $\mathrm{NH}_{3}-\mathrm{N}$ capacity/emissions, TP capacity/emissions, selfpurification rate, phytoplankton diversity index H', Zooplankton diversity index H', Zoobenthos diversity Index H', Aquatic plant diversity index $H^{\prime}$, and $1 /$ Trophic state index) to include in the Aiyi River WECC evaluation system. We took Class IV of the state water quality standards and the water eutrophication indicators as the baseline measures, and determined the evaluation grading standards of the Aiyi WECC.

By establishing the Aiyi WECC model based on a BP artificial neural network, and undertaking quantitative analysis of the Aiyi River WECC, we showed that the Aiyi River's WECC is in normal carrying state in March and July, and weak carrying in May, September, and November. Taking an annual average, the river is in the minimal carrying status.

\section{Acknowledgements}

This study was financially supported by the Major Innovation Projects for Building First-class Universities in China's Western Region (grant No. ZKZD201700), the Key Research and Development Projects in Ningxia Hui Autonomous Region (2016KJHM34), the National Basic Research Program of China (973 Program, 2014CB238903) and the National Natural Science Foundation of China (No. 41672144, 41402133).

\section{Conflict of Interest}

The authors declare no conflict of interest 


\section{References}

1. LIU C.H., SHEN Y.T., ZHOU M.Y., XU H.G., YU L. A quantitative study of urban economic scale constrained by water environmental carrying capacity. Journal of Natural Resource. 28 (11), 1903, 2013.

2. SHI J.P., LI X. Water environment carrying capacity in Dianchi Lake basin and its dynamic variation characteristics. Acta Scientiae Circumstantiae. 32 (7), 1777, 2012

3. GAO W., YAN C.A., LI J.C., LIU Y. An optimization approach for watershed ecological carrying capacity analysis based on coupled water quantity-quality process. Acta Scientiae Circumstantiae. 37 (2), 755, 2017.

4. JIANG D.C., XIAO W.H., FAN C.Y., GONG B.Y. Research on water resources and water environment carrying capacities of Wuhan city circle. Resource and Environment in the Yangtze Basin. 25 (5), 761, 2016.

5. WU Y.C., WANG Z., CAO L., WANG X.J., ZHAO Y.W. Evaluation on water environment carrying capacity of Xuzhou city in recent 10 years based on catastrophe progression method. Bulletin of Soil and Water Conservation. 35 (2), 231, 2015.

6. WANG J.N., YU L., WAN J., XU Y. Assessment on water environmental carrying capacity in the Yangtze River Delta. China Environmental Science. 33 (6), 1147, 2013.

7. WANG S., XU L., YANG F.L., WANG H. Assessment of water ecological carrying capacity under the two policies in Tieling City on the basis of the integrated system dynamics model. Science of the Total Environment. 472, 1070, 2014

8. YANG L.H., TONG L.J. Water environment carrying capacity in the Songhua river basin (Jilin province) based on BP. Journal of Arid Land Resources and Environment. 27 (9), 135, 2013.

9. LI J., ZHOU X.D., CHENG W. Study on annual change in water ecological carrying capacity of the different ecological district of the Taizi River Basin. Journal of China Institute of Water Resources and Hydropower Research. 9 (1), 74, 2011.

10. ZHAI Y.J., WANG L.J., ZHENG B.H., WANG H.X., WANG S.J. Dynamic zoned assessment of ecological carrying capacity of three Gorges Reservoir Area based on system simulation. Research of Environmental Sciences. 28 (4), 559, 2015.

11. THAKUR R.K., JINDAL R., SINGH U.B., AHIUWALIA A.S. Plankton diversity and water quality assessment of three freshwater lakes of Mandi(Himachal Pradesh, India) with special reference to planktonic indicators. Environment Monitoring and Assessment. 185 (10), 8355, 2013.

12. WANG S.C. The analysis and regulation of water environmental carrying capacity. Study on Water Conservancy Development. 2 (1), 2, 2002.

13. DONG F., LIU X.B., PENG W.Q., WU W.Q. Calculation methods of water environmental capacity of surface waters: Review and prospect. Advances in Water Science, 25 (3), 451,2014.

14. ZHU Y., LIANG Z.W., LI W., YANG Y., YANG M.Y., MAO W., XU H.L., WU W.X. Watershed water environment pollution models and their applications: A review. Chinese Journal of Applied Ecology. 24 (10), 3012, 2013.

15. WANG N., LI J.W., XIE J.C. Dynamic research of urban river water environment capacity. Environmental Engineering. 32 (10), 50, 2014.
16. LIAO W.G., PENG J., HE S.Q. Discussion WECC and evaluation system. Journal of China Institute of Water Resources and Hydropower Research. 6 (1), 1, 2002.

17. ZUO Q.T., MA J.X., GAO C.C. Study on carrying capacity of urban water environment. Advances in Water Science. 16 (1), 103, 2005

18. GAO W., CHEN Y., GUO H.C. Coupled model of "assessment-simulation-optimization" for basin environmental economic decision-making. Acta scientiae circumstantiae, 34 (1), 250, 2014.

19. FU G.Z., JIA L., LI C. A study of water environmental capacity in Wuhan city circle. China Rural Water and Hydropower. (11), 48, 2013.

20. LONG P.Y., ZHOU X.D., ZHAO Q.S., LIU X.H. Characteristics and assessment on water environmental carrying capacity. Water Conservancy Science and Technology and Economy. 11 (12), 728, 2005.

21. HE R.M., ZHANG J.Y., WANG G.Q., SONG L.L. Evaluation on generalized water environment carrying capacity based on SPA. Advances in Water Science. 18 (5), 730, 2007.

22. SUN D.Y., YANG J., HU X.Q., JIN Y.Z., ZHANG Y.L. Study on eco-environmental water requirement in the middle-reach oasis of Shulehe River Basin based on ecological protection target. Acta Ecologica Sinica. 37 (3), 1008, 2017.

23. QIU X.C., ZHAO H.X., YIN J. Study on the ecoenvironmental water requirement of AIYI river. Water Saving Irrigation. (8), 63, 2015.

24. ZHOU L.F., ZHAO Z., ZHANG Y L., GUO R. Ecosystem services value based on ecological water of the Hunhe river's main stream. China Rural Water and Hydropower. (10), 126, 2013.

25. QUAN Y., LIU X., WANG C.X., SHAN P., DONG M.T., TANG M.F., WU G. The application of ecological water requirements in the ecological impact assessment of a water conveyance project. Acta Ecologica Sinica. 36 (19), 6012, 2016.

26. SUN D.Y., ZHAO C.Y., WEI H., KOU S.Y., PENG D.M. Eco-environmental water requirement of plain regions in arid inland river basin-a case study on Tailan River Basin in Xinjiang Uygur Autonomous Region. 31 (4), 82, 2011.

27. WANG Z.R., ZHANG X.X., TIAN Y.J. The research system and calculation of ecological water requirement of river basin. Hubei Agricultural Sciences. 51 (15), 3204, 2012.

28. WANG R., HUANG T.Y., WU W. Different factors on nitrogen and phosphorus self-purification ability from an urban Guandu-Huayuan river. Journal of Lake Science, 28 (1), 105, 2016

29. HE B.M., WEI M.X., LI Z. Relations of water self-purify ability with water dynamics, biological and chemical factor in sea-grass bed ecosystem in Tieshan Bay. Marin Environmental Science. 31 (5), 662, 2012.

30. GUO F., WANG W.K., JIANG G.H., MA Z.J. Contaminant transport behavior in a karst subterranean river and its capacity of self-purification: A case study of Lihu, Guangxi. Advances in Water Science. 25 (3), 414, 2014.

31. GONZÁlEZ S.O., ALMEIDA C.A., CALDERÓN M., MALLEA M.A., GONZÁLEZ P. Assessment of the water self-purification capacity on a river affected by organic pollution: application of chemometrics in spatial and temporal variations. Environmental Science and Pollution Research. 21 (88), $10583,2014$.

32. OSTROUMOV S.A. An aquatic ecosystem: A large-scale diversified bioreactor with the function of water self- 
purification function. Doklady Biological Sciences. 374, 514, 2000.

33. ZHAI S.H., HAN T., CHEN F. Self-purification capacity of nitrogen and phosphorus of Lake Taihu on the basis of mass balance. Journal of Lake Sciences. 26 (2), 185, 2014.
34. YANG J., YIN H.W., CHEN X.Q., LI K. Comprehensive evaluation method for self-purification ability of Suzhou Creek in the early period of ecological restoration. Journal of Environmental Engineering Technology. 1 (5), 449, 2011. 
